VOLUME 42 NUMBER 3 AUGUST 2009

\title{
QUARTERLY REVIEWS OF
}

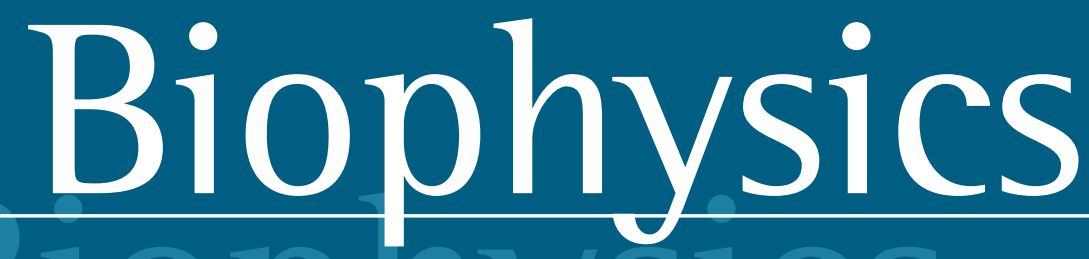

A review journal of biological function, structure and mechanism 


\section{EDITORS}

PROFESSOR BENGT NORDÉN

Department of Chemistry and Bioscience, Chalmers University of Technology, SE-4I 296 Gothenburg, Sweden

DR. WAH CHIU

National Center for Macromolecular Imaging, Baylor College of Medicine, One Baylor Plaza, MS BCMI 25,

Houston, TX 77030, USA

PROFESSOR GERALD F. JOYCE

Departments of Chemistry and Molecular Biology, The Scripps Research Institute,

10550 North Torrey Pines Road, La Jolla, CA 92037, USA

ROGER KORNBERG

Stanford University Medical School, Department of Structural Biology, Fairchild Building, I st floor,

299 Campus Drive, Stanford, CA 94305-5 I 26, USA

DR. ANDREW G. W. LESLIE

FRS, MRC Laboratroy of Molecular Biology, Hills Road, Cambridge CB2 2 QH, UK

PROFESSOR DAVID M. J. LILLEY

FRS, MSI/WTB Complex, University of Dundee, Dow Street, Dundee DDI 5EH, UK

DR. SARA LINSE

Department of Biophysical Chemistry, Lund University, Box 124, SE-22 100 Lund, Sweden

PROFESSOR RODERICK MACKINNON

Laboratory of Molecular Neurobiology and Biophysics, The Rockefeller University, 1230 York Avenue, New York, NY IO02I, USA

DR. J. ANDREW MCCAMMON

Department of Chemistry and Biochemistry, University of California at San Diego, 9500 Gilman Drive, MC0332,

La Jolla, CA 92093-0332, USA

DR. EDUARDO PEROZO

The University of Chicago, The Department of Pediatrics and The Institute for Molecular Pediatric Sciences,

5721 South Maryland Avenue, MC8000, Suite KI60, Chicago, IL 60637, USA

PROFESSOR SUSAN TAYLOR

Howard Hughes Medical Institute, Department of Chemistry and Biochemistry, Department of Pharmacology,

University of California, San Diego, 9500 Gilman Dr. CMM W 125, La Jolla, CA 92093-0654, USA

PROFESSOR GERHARD WAGNER

Department of Biological Chemistry and Molecular Pharmacology, Harvard Medical School, Building C, Room I I2, 240 Longwood Avenue, Boston, MA 0211 , USA

Quarterly Reviews of Biophysics' Editorial Office: Professor Bengt Nordén, Department of Chemistry and Bioscience, Chalmers University of Technology, SE-4I296 Gothenburg, Sweden. E-mail: norden@chembio.chalmers.se

Quarterly Reviews of Biophysics' primary aim is to provide a forum for general and specialized communication between biophysicists working in different areas. This will normally be achieved by inviting authors who have made significant contributions to give a critical and readable account of recent progress in their special fields. Shorter and even controversial articles discussing topics of particular current interest will also be published. Suggestions for reviews can be made to the editors who will provide Instructions for Contributors for the preparation of a manuscript.

Quarterly Reviews of Biophysics (ISSN 0033-5835) is published four times a year in February, May, August and November.

Subscription Rates for Volume 42, 2009: Institutional print and online: US \$680 in USA, Canada, and Mexico; UK £370 + VAT elsewhere; Institutions online only: US \$565 in USA, Canada, and Mexico; UK $£ 310+$ VAT elsewhere; Institutions print only: US \$600 in USA, Canada, and Mexico; UK $£ 325$ + VAT elsewhere; Individuals print and online: US \$245 in USA, Canada, and Mexico; UK $£$ I $27+$ VAT elsewhere; Individual print only: US $\$ 225$ in USA, Canada, and Mexico; UK $\notin 117+$ VAT elsewhere; Single parts available in print only: US \$152 in USA, Canada, and Mexico; UK £85 + VAT elsewhere. Japanese prices for institutions are available from Kinokuniya Company Ltd, P.O. Box 55, Chitose, Tokyo I56, Japan. Orders, which must be accompanied by payment, may be sent to a bookseller, subscription agent or direct to the publishers: Cambridge University Press, The Edinburgh Building, Shaftesbury Road, Cambridge CB2 8RU, UK. Orders from the USA, Canada and Mexico should be sent to Cambridge University Press, Journals Fulfillment Department, 100 Brook Hill Drive, West Nyack, New York I0994-2 133.

Periodicals postage paid at New York, NY, and at additional mailing offices. POSTMASTER: send address changes in the USA, Canada and Mexico to Quarterly Reviews of Biophysics, Cambridge University Press, 100 Brook Hill Drive, West Nyack, New York 10994-2133.

Information on Quarterly Reviews of Biophysics and all other Cambridge journals can be accessed via www.journals.cambridge.org. For further information on other Press titles access www.cambridge.org.

(C) Cambridge University Press 2009

Printed in the United States of America 